\title{
"BARGAINING WITH PATRIARCHY" AND ENTREPRENEURSHIP: NARRATIVES OF MALAY MUSLIM WOMEN ENTREPRENEURS IN MALAYSIA
}

\section{Nor Hafizah Selamat ${ }^{1,2^{*}}$ and Noraida Endut ${ }^{2}$}

\author{
${ }^{1}$ School of Social Sciences, Universiti Sains Malaysia, Pulau Pinang, MALAYSIA \\ ${ }^{2}$ Centre for Research on Women and Gender (KANITA), Universiti Sains Malaysia, \\ Pulau Pinang, MALAYSIA \\ *Corresponding author: hafiz@usm.my
}

Published online: 15 April 2020

To cite this article: Nor Hafizah Selamat and Noraida Endut. 2020. "Bargaining with patriarchy" and entrepreneurship: Narratives of Malay Muslim women entrepreneurs in Malaysia. Kajian Malaysia 38(Supp.1): 11-31. https://doi.org/10.21315/km2020.38.s1.2

To link to this article: https://doi.org/10.21315/km2020.38.s1.2

\begin{abstract}
Achieving gender equality and women's empowerment is integral to Sustainable Development Goals (SDGs) and it has been emphasised that women have a key role in achieving SDGs. Towards the 2030 Agenda for Sustainable Development, what is the reality of gender equality in women's entrepreneurship? The Malaysian government has provided various platforms to increase women's participation in entrepreneurship. However, the relatively meagre research exploring the lived experiences of women entrepreneurs in Malaysia where patriarchy is strongly embedded in the society has created a big gap in the literature. By using the gender lens and Kandiyoti's concept of bargaining patriarchy, this article explores how women entrepreneurs are constantly negotiating and at the same time conforming to patriarchal norms to earn their own "space and freedom" in running and managing their business activities. Ten women entrepreneurs of Amanah Ikhtiar Malaysia (AIM) were interviewed. It is revealed that women entrepreneurs have to constantly juggle their time between performing their domestic duties and their entrepreneurship through constant negotiation with the patriarchal norms. This study offers new insights on negotiating patriarchy used by the women entrepreneurs as a strategy to run their business activities. The gender lens used managed to unravel the fact that Malay Muslim women entrepreneurs are not just
\end{abstract}


passive recipients of patriarchal norms, but consciously and constantly strategise and negotiate their way within the constraints of living in a patriarchal society.

Keywords: Malay Muslim entrepreneurs, bargaining patriarchy, women entrepreneurship

\section{INTRODUCTION}

In 2017, a United Nations forum on sustainable development highlighted the importance of entrepreneurship and innovation for the 2030 Agenda for Sustainable Development. To achieve the agenda, gender equality is fundamental as growth will never be inclusive and poverty will remain when women are continuously disempowered (UN Women Annual Report 2018). Substantial research has been established that women's entrepreneurship has the potential to produce a change in women and empowering women is the key role in achieving Sustainable Development Goals (SDGs) (Lohani and Aburaida 2017; Apostolopoulos et al. 2018; Akhtar 2018; Raghunandan 2018). Entrepreneurship has been addressed in the SDGs under Goal 4 and Goal 8, that is to promote sustained, inclusive and sustainable economic growth, full and productive employment and decent work for all. Hence, towards the 2030 Agenda for Sustainable Development, what is the reality of gender equality in women's entrepreneurship? Have women really been empowered through entrepreneurship? How does this have an impact on our effort to achieve SDGs through entrepreneurship?

Despite the fact that more and more women have actively participated in entrepreneurship, female entrepreneurs in Malaysia still continue to face various challenges (Hasni, Faridahwati and Mohamed Chowdhury 2012; Syed Shah, Mohd Fauzi and Nor Asiah 2011). Recent work in Malaysia by Mazlina and Punitha (2016) reveals that strong support from family members such as spouses and parents is very important. Apart from the economic and structural barriers, not much has been explored on the aspect of gender relations, patriarchal constraints and the process of challenging gender norms except a few (Bianco, Lombe and Bolis 2017). Therefore, this study will specifically focus on these impacts of patriarchal constraints and the process of negotiation among Malay Muslim women in Malaysia. The inherent attitudes of a patriarchal society, that men are superior to women and that women are best suited to play the reproductive roles, pose significant challenges for these Malay Muslim women entrepreneurs. With the exception of few studies in the Middle East (Shmiln 2017; Modarresi et al. 2016; Studholme 2013), the study on patriarchal constraints impacting on Muslim women entrepreneurs particularly in the South East Asian region is scarce. By using a gender lens and the bargaining patriarchy conceptual framework, this 
article will explore how Malay Muslim women entrepreneurs negotiate their patriarchal constraints that have a significant impact on their business sustainability. It also attempts to explore how the patriarchal bargain is being consciously and constantly exploited by women entrepreneurs to earn "space" for them to run and manage their entrepreneurship activities.

\section{LITERATURE REVIEW}

\section{Women Entrepreneurship in Malaysia}

Women's participation in business growth is a universal concern since it is vital for economic development (Global Entrepreneurship Monitor Report 2018). In 2016, nearly 163 million women were starting or running new businesses in 74 economies around the world while an estimated 111 million were running established businesses (Global Entrepreneurship Monitor Report 2018). In Malaysia, various associations of entrepreneurs have been established to provide platforms for women entrepreneurs to establish networks and sharing of information and experiences. However, due to business and family responsibilities, many cannot access the benefit of being in the associations (Xavier 2011). Despite the increase in the number of women in entrepreneurship, successful women entrepreneurs are still low in number (Syed Shah, Mohd Fauzi and Nor Asiah 2011). Nearly one in five small and medium-sized enterprises (SMEs) (19.7\%) are owned by women and $92 \%$ of these SMEs are involved in the service sector (Economic Census 2011).

Amanah Ikhtiar Malaysia (AIM) was established in 1987 to reduce Malaysia's poverty rate by providing financial aids to poor households. There were 303,543 recipients recorded in 2012 (AIM 2014) and 90\% of AIM's recipient are women. In 2018, AIM launched a programme targeting female entrepreneurs to empower them and to support their household living needs. Despite all of these efforts, no specific policy in Malaysia has yet to address grassroots women entrepreneurship due to poor and weak institutions, poor interventions and supporting programmes (Aini Suzana, Shadiya and Akbariah 2017; Rozita et al. 2015). Past studies have documented various challenges faced by women entrepreneurs which include a shortage of peer support networks, lack of capital and access to financial assistance (Maliani and Muhammad Shukri 2017; Aini Suzana, Shadiya and Akbariah 2017; Mazlina and Punitha 2016; Loveline, Uchenna and Karubi 2014). In Malaysia, patriarchal norms and ideology seem to have a significant impact on women's lives. Women are overloaded with the double burden of managing their businesses and of caring for their families (Agarwal and Lenka 2015; Stoner, Hartman and Arora 1990; Rehman and Roomi 2012). As such, women continue to have inadequate entrepreneurial knowledge 
of their surroundings, have limited experience in creating networks and miss the opportunity to participate in activities conducted by the associations (Ghouse et al. 2017; Mazlina and Punitha 2016; Ilhaamie et al. 2014).

\section{Malaysian Context: Patriarchy and Women in Malaysia}

Malaysia is a multiracial country consisting of Malays, Chinese, Indians and other Bumiputeras. In 2016, there were 16.4 million males and 15.3 million females, totalling an estimated 31.7 million population (Department of Statistics Malaysia 2016). Malaysia is still considered as a patriarchal society and these patriarchal cultural practices have significantly influenced the societies' moral values and social structure as documented in the histories and ethnographic character of Malaysia (Wazir Jahan 1995). Patriarchal gender relations in Malaysia have been laid down since the arrival of early Islam in the 13th century, followed by the British colonial powers in the 19th century (Rohana 1999). Despite the fact that more women today are earning wages outside the home and some are getting higher wages than their spouses, the patriarchal belief still strongly prevails in most Malaysian families. This has been reinforced by the diverse religious mores within the country (Rohana 1999). Although formal and informal barriers to participation in civil society such as in education, economic and political spheres have been eradicated, most women are still in a disadvantaged position because they are expected to play a disproportionate role in domestic work (Hirschman 2016). The layers of disadvantage women experience as a result of their gender, age, poverty and ethnicity have been widely discussed in the literature (Hochschild and Machung 1989; Rashidah, Noraida and Diana 2016), but unfortunately the exploration of the relationship between patriarchal traditions and entrepreneurship is rather limited.

\section{Gender Roles, Entrepreneurship and Bargaining Patriarchy}

Patriarchy refers to a system of social structures and practices that give men control over women's production, reproduction and sexuality (Walby 1990). These unequal power relations between men and women are strengthened by the masculinity and femininity character stereotypes imposed by society. In the classical literature on entrepreneurship, entrepreneurs have often been associated with masculinity and entrepreneurship itself is a form of masculinity (Pines, Lerner and Schwartz 2010). However, Bruni, Gherard and Poggio (2004) argue that gender and entrepreneurship should not be viewed as "substances" but rather as "practices learned and enacted at suitable occasions". Based on her work, she showed how the codes of a gendered identity are kept, changed and transgressed by constantly 
sliding between different symbolic spaces. Many women have prioritised their domestic roles and responsibilities over immersion in entrepreneurial activities. As for Mulholland (1996), he sees entrepreneurship of women as an extension of male power from the domestic sphere to the productive one. These forces of patriarchy are the major challenges for women entrepreneurs, as the concept of "chastity" or honour places severe restrictions on their mobility and it might cast doubts on their reputation (Mushtaz and Shazia 2011). In Muslim countries such as Malaysia, the concept of permission (izin) and honour have greatly influenced the social mobility of women. Wives need to ask for permission from their spouses in many aspects of their lives. Yusuf (2013) argues that in a patriarchal society, gender, ethnicity and religion also play an important role in entrepreneurship development and the manner women entrepreneurs are perceived and valued. In Pakistan, for example, due to the discriminative sociocultural values and norms, many women entrepreneurs do not get equal opportunity as much as male entrepreneurs (Ghazala, Rana and Amer Hamzah 2018; Rehman and Roomi 2012) because women are expected and more suited to become mothers and homemakers.

The analysis of the different patriarchal structures in the different regions of South Asia and the Middle East has been offered by Kandiyoti (1997). Bargaining patriarchy refers to various tactics in which a woman chooses to accommodate and uphold patriarchal norms, accepting gender roles causing disadvantages to women, with the objective to realise their own power and options. She finds great contrast in the operation of patriarchal structures in the Middle East, Africa and South Asia, revealing the different facets of patriarchal structures and their possible impact on women lives (Kandiyoti 1997, 275). She also argues that women have very little to gain and much to lose by becoming totally dependent on husbands, and they resist projects that tilt the delicate balance and strive to safeguard their autonomy. Women strategise within a set of concrete constraints, which she identified as "patriarchal bargains". She argues that different forms of patriarchy present women with distinct "rules of the game". Therefore, different strategies will be utilised to maximise security and optimise life options with varying potential for active or passive resistance in the face of oppression. Thus, the patriarchal bargain is all about these strategies and negotiations to "resist" dominance. A study by Studholme (2013) revealed that Saudi women are forced to conduct themselves, strategise and negotiate within the constraints of living in a "classic patriarchal" culture despite the government's symbolic efforts in encouraging women into entrepreneurship. $\mathrm{He}$ also argues that the entrepreneurs bargained within the patriarchal boundaries across the spheres; the domestic, society and the state regulations, and cleverly negotiated these permeable boundaries in order to overcome them, and thus were not passive victims of the system. However, whilst the women exercised some agency within the structure, the overall patriarchal system prevailed. 


\section{THEORETICAL FRAMEWORK}

In this study, the bargaining patriarchy perspectives and gender lens are used as the conceptual framework to analyse women's strategies and coping mechanisms that can lead us to a more culturally and temporally grounded understanding of patriarchal systems, different from the abstract notion of patriarchy encountered in contemporary feminist theory (Kandiyoti 1988). In this context, Kandiyoti (1988) argues that a patriarchal bargain is a decision by women in a misogynistic culture to employ different tactics to reinforce the notion of men's superiority or conforms to patriarchal demands of her gender in order to achieve something, get ahead or just to survive. A patriarchal bargain can also be seen as a tool to make a choice or decision to accept gender rules in exchange of whatever power. It can also represent strategies made by individuals to manipulate the system but at the same time maintaining the status quo of the system. The concept of bargaining power has been researched particularly in a spousal relationship as shown in the work of Agarwal (1997) and Gram et al. (2018). In the literature of gender entrepreneurship (Mulholland 1996; Bui, Kuan and Chu 2018), the theme of entrepreneurship interweaves with patriarchy in two dimensions such as private patriarchy and the public patriarchy. It is argued that the construction of entrepreneurship as a form of masculinity has not worked simply through male bodies but also through the images and representations associated with masculinities, some of which are more aggressive and geared to personal profit, others being more altruistic and intended to ensure the economic well-being. Entrepreneurship is a space for women to produce changes through resistance and accommodation strategies (Bianco, Lombe and Bolis 2017). Within this framework, this study will analyse the narratives of Malay Muslim entrepreneurs in their entrepreneurship activities.

\section{METHODOLOGY}

This study is based on the qualitative approach that provides rich descriptions of processes (Richards 2009), facilitates induction of patterns (Yin 2003) and is recommended for entrepreneurship research (Cope 2011). A series of indepth interviews were conducted with 11 women entrepreneurs and also AIM recipients. The sample of respondents was selected based on the AIM registered list. The narrative research design was employed to illuminate how events unfold temporally, descriptions of past events that provide insights into people's thoughts, emotions and revealing the meaning of experience (Elliot 2005; Richards 2009; Thomas 2012). The interviews recorded in an audio-tape were semi-structured. 
The interview consists of questions on women's role and responsibility, their livelihood assets and opportunities that they have access to, as well as issues of power and decision-making in the household and business management (Table 1).

Table 1: Details of respondents

\begin{tabular}{lccl}
\hline Pseudonym & Marital status & Age & Type of business activity \\
\hline Seri & Married & 51 & Frozen curry puff \\
Hawa & Married & 29 & Bakery \\
Hasiah & Married & 49 & Tailoring \\
Imah & Married & 42 & Tailoring \\
Ikin & Married & 38 & Beading shop \\
Hani & Married & 33 & Casual dress \\
Salmah & Married & 37 & Aerobics instructor \\
Nora & Married & 46 & Masseuse \\
Puji & Married & 52 & Chili paste \\
Azizah & Married & 39 & Laksa food stall \\
Khairunisa & Married & 43 & Tailoring \\
\hline
\end{tabular}

\section{DATA ANALYSIS AND FINDINGS}

The discussion of the narratives will be divided into two; the first section will look at their entrepreneurial experiences and motivations while the second section focuses on their business challenges and how the patriarchal bargain process occurs.

\section{"I Can See My Potential": Entrepreneurial Experiences and Motivations}

Motivation is a significant factor in the start-up and success of women entrepreneurship. In Malaysia, women are drawn to entrepreneurship by "pull factors" such as the need for independence, self-satisfaction, sources of finance, desire to be recognised by the society and the urge to try to do something on their own (Global Entrepreneurship Monitor Report 2018; Maliani and Muhammad Shukri 2017; Iklima Husna, Noor Fzlinda and Sharon Toh 2017). In this study, all participants claimed that they already considered themselves as having successful businesses, but they were not necessarily successful businesswomen. To them, having a successful business means earning good profit and not just surviving. 
The majority of them had embarked into business to generate income for their families. Seri, 51, who runs a homemade frozen curry puff business, said that:

I'm doing [business] this as part of my responsibility to increase my household income. Besides frozen curry puff, I also used private functions such as wedding to utilise my skills by making some traditional Malay cookies for these occasions. I take orders, particularly from neighbours and friends in the village. The money I earn is not only for myself but more importantly for my family such as buying groceries.

Another participant, Nora, 46, decided to start the massage business after accompanying her mother, who has been a masseur for many years. While observing her mother at work, she slowly picked up the skills. One day, her mother was ill and asked Nora to replace her. One year later, she decided to focus on the massage business as she realised that she could earn more money than from helping her husband who owned a clothes alteration shop. In this study, the participants described how the day to day running of the business depends on their sole decision-making. Puji, 52 years old, is a successful blended chilies entrepreneur who once received the most popular AIM loan recipient award. For six years with AIM, she was among the AIM members that paid the highest repayment loan weekly. She pays AIM RM1,500 on a weekly basis which totalled up to RM6,000 per month. The high monthly repayment loan also an indication of the amount of income generated from the business. In terms of business decision-making, Puji said she made most of the business decisions, including the decision to give half of her blended chilies business to her husband so that he could open another branch elsewhere. She told her husband that he could take half of her business because "It [the business] is easy money". Her husband was a police officer but resigned when they got married and decided to join her family business. In fact, Puji helped him to set up the new branch. She narrates:

When he opened the new branch, I gave him the start-up capital. I bought him a blender machine that cost me RM5,000. I paid the rental deposit for the new shop. I said to him, "here's the money, you go and find the machine, we do it together... I teach you how to do it". Then, he hired workers. I taught him all that.

When asked why she supported him in his new business, Puji responded by saying that she felt that she had to help her husband as she was more experienced than he was. She had to help him financially because his own grocery store business was taken over by his siblings when he got sick. Due to a lack of business experience, the store did not survive. Although she tried her best to help by adding more stocks for the store, the store eventually had to be closed down. It was then that Puji suggested him to get involved in blended chilies business. When her husband fell 
ill, she had to pay all medical bills. Now Puji has three workers and another two workers were helping her husband's business. Interestingly, when suggested that she was actually the "leader" of her business, she tried to downplay her dominant role in her business by saying that she was just the "backbone" for her husband. Although she refused to be seen as the "leader" in her family, she did not refute the fact that her husband heavily depended on her. While Puji was born in a family business, Hasiah started her tailoring business because it was her passion. Hasiah, 49 years old, has been a full-time housewife since she got married at the age of 22. She has never worked before nor has she any interest in work. Instead, she put her heart to care for her seven children (six boys and one girl) and managing the house. She narrates, "I manage my children with my bare hands. I also love doing tailoring. It's my hobby. I don't like working. When I've done my housework, then I start my sewing".

The narratives show that the women entrepreneurs had the skills and experience and most of them decided to utilise their "passion" to embark into a business. In the next section, the discussion will show how the concept of permission is an important aspect that can either limit or enhance their mobility. This mobility is an important element in the lives of women entrepreneurs as it can have a significant impact on their business performance.

\section{"Success Without Being Obedient (Taat) Is Nothing": Business Challenges and the Patriarchal Bargain}

It has been argued that success in entrepreneurial business is multidimensional which includes the survival of the firm, business performance, personal satisfaction, reward attainment, life satisfaction and cultural attitudes towards entrepreneurship (Sitinor Wardatulaina et al. 2017). In terms of gender, women view differently the concept of entrepreneurial success. Some women define success as having control over their own destinies, building ongoing relationships with clients and doing something fulfilling while other factors that influence women entrepreneurial success are human capital, networking, financial aids and opportunity (Shamsul Hana and Norashidah 2017). Other factors affecting female entrepreneurial success can be found and organised at the internal (individual), micro, meso and macro environment level (Cabrera and Mauricio 2017). Others described success in terms of children, satisfaction in works, reputation, ability to choose the daily activity, their contribution to the community and their overall perceived quality of life (Artz 2017; Maliani and Mohamad Shukri 2017). Although more women are embracing entrepreneurship, they often face challenges not typically shared by their male counterparts. Work-life balance seems to be the most challenging task for women entrepreneurs and traditional gender expectations often become their constraints. 
In this study, although the majority of women entrepreneurs have adequate experience as businesswomen and have a deep interest in the business, they still have to face various challenges that have a huge impact on their business operations and eventually their business performance. One of the main challenges is to shoulder the double burden of managing the families and the business. Seven out of eleven participants operated their businesses from home due to family responsibilities. Doing business from home is viewed by the majority of participants as a strategy to earn income and at the same time be able to perform their main task as housewives. In this study, several participants used their home as "business space" so that they can perform both roles as a homemaker and business operator. They claimed that they run the business in between school time and housework. This is admitted by Azizah, 39, who runs a laksa (rice flour noodle) business in her house's compound. Azizah claims that she has to juggle her time between the business and caring for the kids as she does not want to burden her husband. She said her husband would give permission to do business as long as the house is properly managed. She said:

That's why I don't want to burden him [with housework] because I understand what he meant and his expectation. It's tiring but at least I can earn money to help my family. I usually start my business when my kids are already at school, as I have more time to entertain my customers. That's why I run my business in my house's compound because I can look after my children, do domestic chores and do my business at the same time.

The narrative shows the "bargaining" process, where they still have to perform their gender roles based on the expectations imposed on them so that the "permission" is granted. Many participants argued that the gender roles expectations and the bargaining process in order to be given "permission" to run their businesses have indeed required their patience and energy. The issue of children safety is another major reason that forced many participants to operate their businesses from home. Ikin, a 38-year-old mother of three boys had to relocate her business premise from town to her own home. Ikin worked in the banking sector for 15 years before moving to a private company. Unfortunately, working and at the same time having small children was too big a challenge for her. Concerned about her children's welfare, Ikin quit her job and began to take a tailoring course. She then opened a tailoring shop upon completion of the course. Again, the challenge of doing business and taking care of children resurfaced as she had to care for the kids and entertain customers as well. She became worried about their safety as one of her children was still five years old. After one year in the business, she had to relocate her business operation to her own home. Sadly, the new business premise was not strategic enough to attract customers, thus affecting her income. She began 
to reinvent her business by specialising in beading. The idea of doing beading emerged when she noticed that skilled bead sewers were in demand particularly from boutique owners. Starting with sewing beads for neighbours and friends, her skills in creating the design in bead sewing improved. Starting with RM15 per dress, she could now earn around RM120 per dress. Previously, she used one of her rooms in the house for beading activity, stocking more than 10,000 beads in the room. Now, almost 12 years in the business, she is a proud owner of her beading shop. Everything was smooth sailing until when her husband retired. Ikin narrates:

I am very business minded [person], but my husband is not. He used to work and get paid. All this while, I made my own decision. Then last year, he retired. Now, most of the decisions are determined by him, and he is basically against most of my decisions. Like when I made a booking to rent another shop, he disagreed as he thought that would cost more money (to invest).

This latest scenario, according to Ikin, has affected her business expansion plan. This is where the bargaining process for her occurs. Although she was really upset with most of her husband's decisions, she did not want to upset him further by objecting to his decisions. If she resisted, she might not even get permission to operate her business. She was basically conformed and obeyed his decisions as a strategy for her to be given "freedom" to continue her business or even to reduce the restrictions on her mobility. But conforming to his decisions would also mean that she operates the business within the "constraints" of her husband's permission (izin). This is what Kandioyati refers to as patriarchal bargain in which woman would try to conform so that she would be left alone in operating the business. In some cases, several other participants only faced the disapproval from their spouses during the start-up phase. The participants in this study strongly agree to the suggestion that spouse's support would make a significant impact on their dayto-day running of the business and its performance. This point was illustrated by Salmah, 37 years old and an aerobics instructor, in the following narrative:

I think [we] can be successful...but it depends on our rezeki. If there is pressure, it can affect the business. Sometimes the pressure comes from unsupportive husband...not supportive in terms of finance and morale. Sometimes [he] condemns our effort in the business, cynical about the income generated. Eventually, that will affect our mind and can create stress. It's even more stressful if we have to handle the children alone. Then, there are pressures from both families (paternal and maternal). All these can create stress. 
The narrative above confirms the previous study that firms run and owned by female entrepreneurs were often at a commercial disadvantage because of pressures on them to prioritise family responsibilities over their entrepreneurial career (McGowan et al. 2012). Salmah shared her experience of the pressure she faced from her husband, particularly during her initial stage in the business. She narrates:

\begin{abstract}
When I decided to take the beginner's aerobic course, my husband really put so much pressure on me. He began to question whether I was really serious, or could I really do it? It really affects my sense of confidence, [as I am] not sure whether taking the class would be a good idea. After enrolling, I have to work hard to prove it to him that I can. When I finally completed the course, I showed the certificate to him. He was still sceptical about it. One day, I got paid for conducting an aerobics class in one of the functions in the village. It was then he realised that my aerobics skills could actually generate income.
\end{abstract}

Despite the fact that she finally obtained the "permission" from her husband to become an aerobics instructor, she still had to prove to him that she could manage the domestic chores including taking care of her seven children. She had to prove to her husband that she can manage the domestic responsibilities while doing business so that she can obtain permission and earn her "freedom" to keep the business. This is another type of patriarchal bargain practiced mostly by these women entrepreneurs. Although this "double burden" is challenging for them, the participants claimed that they had to carry the double burden as a strategy to get permission to run the business. Balancing between family and business and worrying about societal acceptance become a major challenge faced by these women entrepreneurs during the early stage of their businesses.

It was a good ending for Salmah to finally secure the permission from her husband, but that was not the case for Khairunisa, a single mother for eight years before she remarried with a police inspector. Khairunisa grew up in a business family, was involved in various kinds of businesses from selling satay to becoming a spokesperson for multilevel marketing (MLM) products, owned several boutiques and also a tailoring shop. She said that the best business ventures she ever had were when she was still a single mother. She described her eight years as a single mother as "flying high...very high". She described herself as "very fast, outspoken and multitalented" person. She narrates:

I just remarried. Before this...I fly high. I was a spokesperson for a direct selling company and a representative of a company from Kuala Lumpur, the capital city of Malaysia that opens a branch in my hometown [in East Malaysia]. So, almost $80 \%$ of the branch agents were under my 
leadership. I was like an artist. People often recognised me as "that woman who goes on stage". I am a Muslim convert. My Muslim foster family is in the food business. They sell satay with stores in several places over there. The satay business is still famous until now. I used to own two boutiques. But that was history. After I remarried, I moved to Kuala Lumpur to be with my husband.

When asked about her husband's support towards her business, this is what Khairunisa had to say:

At first, he was supportive... but when it comes to authority... he always gives orders. He's an inspector by the way. So, sometimes he did not give [permission], so quite limited [freedom]. When I got pregnant, I suffered a prolonged cough for nine months. I was still the product spokesperson, but I could not get onto the stage. I started taking MCs throughout my eight months of pregnancy, I coughed a lot and there were no sales. When there were no sales, I had to quit, although I was promoting a great product.

The narrative shows how having good support from family members, particularly the spouse will to a certain extent determine the success of women entrepreneurs. This is due to the patriarchal norms such as asking permission as practiced in the family. This concept of asking permission is so subtle but significant as all of them believe that it is compulsory (wajib) but according to them their spouses may use this permission as a tool to control their mobility. They argue that to be successful entrepreneurs, the freedom of mobility is critical especially when they have to do marketing and meet customers. Several participants in this study share similar views on how this concept of permission was being used to control their mobility. This situation was best illustrated by Hasiah, one of the skilled tailors in her town. Hasiah owns only a small tailor shop but her expertise has been sought after by boutique owners. She was a very motivated and visionary entrepreneur and when asked about her husband's support, she narrates:

My husband never stops me [from doing anything] because he can see that I already spent most of my time at home. That was my choice. Even now I still prefer to stay at home. In the morning I will prepare breakfast and lunch for my children, then after afternoon prayer, I will go to my shop. I have to pray at home because there is no proper place for prayer at the shop. I make all the decisions and he never go against my decisions. He never interferes in my work as he is also working in a hotel. He does his things, I do mine. He gives me all the trust and I have to keep that trust, don't go beyond that. He wants me to spend more time with the family and not do other things. 
However, when probed further, Hasiah revealed an interesting fact. She could foresee that her ultimate dream to have her own clothes factory may not materialise because of the permission issue. She described her husband as very protective and controlling. She said:

I have no problem so far [with the business] but my only problem is that my husband did not like me to move forward (to expand the business). He did not want me to "step further beyond what I am doing right now", which means I may not able to expand my business as I will not get his approval.

Hasiah always viewed herself as someone who has what it takes to expand her business but was disapproved by her husband because:

From his view, I am already successful [as businesswoman]. He saw Chinese businessmen who run their businesses at the same place as mine can make a good sale like me. He said my sale is already good like them and they can become millionaires. So, he said I don't need to go beyond that. I know that he is a bit protective. He thought that if I do that, then I would spend most of my time outside the home and having less time with children and family, and less time for akhirat [religious practices]. He does not want that. He said that we should not pursue worldly things only as we have different levels [in life]. It should be balanced. I don't know. Sometimes, I think, it is just his character that I should not be (achieving) more than he does.

The narrative presents how certain words, for example, the concept of taat (obedience) were utilised as a subtle "pressure" by her husband to remind her of her main obligations. These words have been consistently uttered by her husband, putting more pressure on Hasiah to focus more on her role as a wife instead of business. This can be considered as "subtle expressions of patriarchy" as argued by Desai and Krishnaraj (2004). According to them, these subtle expressions of patriarchy can be seen through symbolism giving messages that reinforce the inferiority of women through legends, highlighting the selfsacrificing, self-effacing pure image of women and emphasising the dominant role of women as a faithful wife and devout mother (Desai and Krishnaraj 2004). Interestingly, Hasiah downplayed her husband's "subtle expression of patriarchy" by emphasising the importance of being taat (loyal) towards her husband. She, in fact, described her husband as the "best husband". This narrative is evidence of this bargaining patriarchy practices when Hasiah conformed to her husband's decision to avoid him disrupting her existing business operations. The fact that he was quite supportive at home has forced Hasiah not to object his decision. She accepted the fact that her business would remain as usual with no planning 
of business expansion. Therefore, whilst women did exercise agency at some permeable boundaries, this agency remained within the confines of a prevailing patriarchal structure (Studholme 2013). This concept of agency shows that women do exercise "choice" or "choose" survival within the structural constraints of the patriarchal institutions and ideologies.

\section{DISCUSSION}

In this article, we argue that women cannot be understood simply as passive victims of patriarchal constraint. The challenges and the patriarchal bargain processes that these women entrepreneurs have to go through for the survival of their businesses have been illustrated. Initially, however, the majority of participants were not aware of the impacts of patriarchal norms as a barrier to their business success as these patriarchal practices are often viewed as "normal" in their life. The narratives also suggested that the spouse's permission affected women's mobility. Spatial mobility is one of the major challenges for Muslim women in entrepreneurship due to the inherent attitude of a patriarchal society such as in Pakistan (Roomi and Parrot 2008). The forces of patriarchy are very much related to the concept of "chastity" or honour that place severe restrictions on their mobility (Mushtaz and Shazia 2011). Confronted with gender roles and expectations together with the limited power in the decision-making process, women are faced with limited mobility. This is evidenced through the narratives of the participants in this study. In a patriarchal society such as Malaysia, the concepts of izin and honour have a great influence on the social mobility of women.

As indicated by the majority of the participants, they strongly believed that wives need to seek permission from husbands in many aspects of their lives. As a Muslim, they acknowledge that Islam allows women to be involved in any business activities with two conditions however, to look for husband's endorsement and the business ought not to be the reason for the breakdown of the family. This finding shows that women entrepreneurs are often constrained by limited mobility when they need to seek constant approval from their husbands, particularly for a major decision and planning such as business expansion. This is the reason why the patriarchal bargain is a daily practice. Without bargaining, permission might not grant, thus, mobility will be limited. This limited mobility in relations to patriarchal practices has been widely documented in other countries such as Pakistan, India and Africa (Rehman and Roomi 2012). In many cases, scholars argue whether this constrained access would really empower women (Gill and Ganesh 2007). Other than seeking permission, family obligations and the primary responsibility for children, home and older dependent family members also restrict women's mobility in entrepreneurship (Kain and Sharma 2013). 
Sociocultural pressures can be the additional challenges that restrict women's mobility in business. In South Asian societies, women's role is greatly influenced by two factors namely the cultural norm of purdah ${ }^{1}$ and the notion of $i z z a t^{2}$ (Papanek 1982). The institution of purdah has been extensively criticised as the cause of women's restricted mobility particularly in the Middle East and South Asia and eventually becomes a barrier to the improvement of women's economic fortunes. This has indeed put them in a disadvantaged situation, particularly when they have to be in an environment in which "being masculine" is necessary. In this study, the "bargaining" was done by conforming to the "patriarchal norms" that will eventually provide them a space to maximise their potential and freedom in decision-making in entrepreneurship activities. They also illustrate the nature of the "permeable boundaries" within and across the patriarchal domestic, societal and state domains, which means that women are paradoxically confronted with "enabling" opportunities and "constraining" boundaries in each of the domains. The findings are in parallel to what has been found in Saudi Arabia (Roomi and Parrott 2008).

\section{CONCLUSION}

This study provides a significant indication that knowing how culture shapes entrepreneurial intentions could be useful to examine the gender gap in entrepreneurship. In Malaysia where patriarchal practices are strongly embedded in the social structure of the society, more effort is needed for relevant agencies to understand better the effect of gender inequality in entrepreneurship. Since this study has a limited number of participants, future research may include different socioeconomic groups of women entrepreneurs to explore the effect of patriarchy in entrepreneurship. Gender-sensitive policies and good practices need to be developed to provide an effective ecosystem to support women entrepreneurship. A clear gender-sensitive policy will eliminate some of the biases that limit women's access to mobility. This is critical as inclusive sustainable development can only be realised when all human rights - including gender equality - are protected, respected and fulfilled.

\section{ACKNOWLEDGEMENTS}

This article is based on a study entitled "Gender and Entrepreneurship Performance: Towards a Theoretical Model of the Gender Analyses of Microfinance (MFs) Borrowers in Entrepreneurship" funded by Universiti Sains 
Malaysia under the Fundamental Research Grant Scheme (FRGS) Research, No: 203/PKANITA/6711418. The research team would like to thank Ministry of Education, Malaysia for funding this project through its FRGS.

\section{NOTES}

1. According to Papanek (1982), purdah is a significant instrument of sexual segregation and seclusion based on spatial boundaries that determine women's activities to be confined in the domestic area while men are free to work outside.

2. Izzat is referring to shame and honour that can be brought to others by one's own behaviour and women are repositories of a family's honour and therefore their chastity and good reputation must be constantly guarded (Roomi and Harrison 2010; Shaheed 1990).

\section{REFERENCES}

Agarwal, S and U. Lenka. 2015. Study on work-life balance of women entrepreneurs review and research agenda. Industrial and Commercial Training 47(7): 356362. https://doi.org/10.1108/ict-01-2015-0006

Agarwal, B. 1997. "Bargaining" and gender relations: Within and beyond household. Feminist Economics 3(1): 1-51. https://doi.org/10.1080/135457097338799

Aini Suzana Ariffin, Shadiya Mohamed Saleh Baqutayan and Akbariah Mohd Mahdzir. 2017. Enhancing women entrepreneurship development framework: Policy $\&$ institution gap and challenges in the case of Malaysia. Journal of Science, Technology and Innovation Policy 3(2): 1-12.

Akhtar, S. 2018. To achieve gender equality, we need women entrepreneurs. IndraStra Global 4(3): 1-3.

Amanah Ikhtiar Malaysia (AIM). 2014. Sejarah awal AIM. http:// www.aim.gov.my/index .php/kenali-kami/2013-03-14-14-20-42/sejarah.html (accessed 5 March 2018).

Apostolopoulos, N., H. Al-Dajani, D. Holt., P. Jones and R. Newbery, eds. 2018. Entrepreneurship and sustainable development goals 8. UK: Emerald Group Publishing Limited. https://doi.org/10.1108/s2040-724620188

Artz, B. 2017. Gender and entrepreneurial success: Evidence from survey data. Applied Economics Letters 24(3): 163-166. https://doi.org/10.1080/13504851 .2016 .1173173

Bianco, M., M. Lombe and M. Bolis. 2017. Challenging gender norms and practices through women's entrepreneurship. International Journal of Gender and Entrepreneurship 9(4): 338-358. https://doi.org/10.1108/ijge-10-2017-0060

Bruni, A., S. Gherard and B. Poggio. 2004. Doing gender, doing entrepreneurship: An ethnographic account of intertwined practices. Gender, Work and Organization 11(4): 407-429. https://doi.org/10.1111/j.1468-0432.2004.00240.x 
Bui, H., A. Kuan and T. Chu. 2018. Female entrepreneurship in patriarchal society: Motivation and challenges. Journal of Small Business \& Entrepreneurship 30(4): 325-343. https://doi.org/10.1080/08276331.2018.1435841

Cabrera, E. and D. Mauricio. 2017. Factors affecting the success of women's entrepreneurship: A review of literature. International Journal of Gender and Entrepreneurship 9(1): 31-65. https://doi.org/10.1108/ijge-01-2016-0001

Cope, J. 2011. Entrepreneurial learning from failure: An interpretive phenomenological analysis. Journal of Business Venturing 26(6): 604-623. https://doi.org/10.1016/ j.jbusvent.2010.06.002

Department of Statistics Malaysia. 2016. Official website. https://www.dosm.gov.my/v1/ (accessed September 2018).

Desai, N and M. Krishnaraj. 2004. An overview of the status of women in India. In Class, caste, gender, ed. M. Mohanty, 296-319. New Delhi: Sage Publications.

Economic Census. 2011. SMEs urged to take part in Census 2011. https://www.dosm .gov.my/v1/images/stories/files/menu/General/MALAYSIA_SME_18 Jun2011_ SMEs_urged_to_take_part_in_Census2011.pdf (accessed January 2019).

Elliot, J. 2005. Using narrative in social research: Qualitative and quantitative approaches. Thousand Oaks, CA: Sage.

Ghazala Khan, Rana Tahir Naveed and Amer Hamzah Jantan. 2018. Status of wonder women: Challenges for young future women entrepreneurs in Pakistan. International Journal of Experiential Learning \& Case Studies 3(1): 97-109. https://doi.org/10.22555/ijelcs.v3i1.1838

Ghouse, S., G. McElwee, J. Meaton and O. Durrah. 2017. Barriers to rural women entrepreneurs in Oman. International Journal of Entrepreneurial Behavior \& Research 23(6): 998-1016. https://doi.org/10.1108/ijebr-02-2017-0070

Gill, R and S. Ganesh. 2007. Empowerment, constraint, and the entrepreneurial self: A study of white women entrepreneurs. Journal of Applied Communication Research 35(3): 268-293. https://doi.org/10.1080/00909880701434265

Global Entrepreneurship Monitor (GEM) 2017/2018 Report. 2018. https://www .gemconsortium.org/report/50012 (accessed October 2018).

Gram, L., J. Skordis-Worall, J. Mannel, D. Manandhar, N. Saville and J. Morrison. 2018. Revisiting the patriarchal bargain: The intergenerational power dynamics of household money management in rural Nepal. World Development 112: 193-204. https://doi.org/10.1016/j.worlddev.2018.08.002

Hasni Che Ismail, Faridahwati Mohd. Shamsudin and Mohamed Chowdhury. 2012. An exploratory study of motivational factors on women entrepreneurship venturing in Malaysia. Business and Economic Research 2(1): 1-13. https://doi .org/10.5296/ber.v2i1.1434

Hirschman, C. 2016. Gender, the status of women, and family structure in Malaysia. Malaysian Journal of Economic Studies 53(1): 33-50.

Hochschild, A. and A. Machung. 1989. The second shift: Working families and the revolution at home. New York, NY: Viking.

Iklima Husna, Noor Fzlinda Fabeil and Sharon Toh Pei Sung. 2017. Motivator and challenges of women entrepreneurs. Journal of Global Business and Social Entrepreneurship (GBSE) 1(3): 111-121. 
Ilhaamie Abdul Ghani Azmi, Siti Arni Basir, Rosmawani Che Hashim and Hassan AlBanna Mohamed. 2014. Challenges of Muslim women entrepreneurs in Malaysian SMEs. International Journal of Innovation, Management and Technology 5(6): 428-433. https://doi.org/10.7763/ijimt.2014.v5.553

Kain, P. and M. Sharma. 2013. Women entrepreneurship education need for today. Journal of Management Sciences and Technology 1(1): 43-53.

Kandiyoti, D. 1988. Bargaining with patriarchy. Gender and Society 2(3): 274-290. 1997. Gendering the modern: On missing dimensions in the study of Turkish modernity. In Rethinking modernity and national identity in Turkey, eds. S. Bozdoğan and R. Kasaba. Seattle and London: University of Washington Press. https://doi.org/10.1017/s0017257x00004516

Lohani, M. and L. Aburaida. 2017. Women empowerment: A key to sustainable development. The Social Ion 6(2): 26-29. https://doi.org/10.5958/2456-7523.2017.00006.4

Loveline, A.A., O.I. Uchenna and N.P. Karubi. 2014. Women entrepreneurship in Malaysia: An empirical assessment of the challenges faced by micro and small business owners in Kuching-Sarawak. International Journal of Humanities Social Sciences and Education (IJHSSE) 1(4): 48-58. https://doi.org/10.9790/0837-19426773

Maliani Mohamad and Muhammad Shukri. 2017. Malay Women entrepreneurial success: Challenges and barriers. International Journal of Accounting, Finance and Business 2(5): 76-84.

Mazlina Mustapha and Punitha Subramaniam. 2016. Challenges and success factors of female entrepreneurs: Evidence from a developing country. International Review of Management and Marketing 6(S4): 224-231.

McGowan, P., C.L. Redeker, S. Cooper and K. Greenan. 2012. Female entrepreneurship and management of business and domestic roles: Motivations, expectations and realities. Entrepreneurship and Regional Development 24(1-2): 53-72. https://doi.org/10.1080/08985626.2012.637351

Modarresi, M., Z. Arasti, K. Talebi and M. Farasatkhah. 2016. Women's entrepreneurship in Iran: How are women owning and managing home-based businesses motivated to grow? International Journal of Gender and Entrepreneurship 8(4): 446-470. https://doi.org/10.1108/ijge-03-2016-0006

Mulholland, K. 1996. Gender power and property relations within entrepreneurial wealthy families. Gender, Work and Organization 3(2): 78-102. https://doi.org/ 10.1111/j.1468-0432.1996.tb00050.x

Mushtaz Ahmad and Shazia Naimat. 2011. Networking and women entrepreneurs: Beyond patriarchal traditions. African Journal of Business Management 5(14): 57845791.

Papanek, H. 1982. Purdah in Pakistan: Seclusion and modern occupations for women. In Separate worlds, eds. H. Papanek and G. Minault. Delhi: Chanakya Publications.

Pines, A., M. Lerner and D. Schwartz. 2010. Gender differences in entrepreneurship: Equality, diversity and inclusion in times of global crisis. Equality, Diversity and Inclusion: An International Journal 29(2): 186-198. https://doi.org/ $10.1108 / 02610151011024493$

Raghunandan, V. 2018. Changing equations: Empowerment, entrepreneurship and the welfare of women. Journal of International Women's Studies 19(3): 1-13. 
Rashidah Shuib, Noraida Endut and Diana Wong, eds. 2016. Debating gender justice in Asia. Pulau Pinang: Universiti Sains Malaysia.

Rehman, S. and M.A. Roomi. 2012. Gender and work-life balance: A phenomenological study of women entrepreneurs in Pakistan. Journal of Small Business and Enterprise Development 19(2): 209-228. https://doi.org/10.1108/ 14626001211223865

Richards, L. 2009. Handling qualitative data: A practical guide. Thousand Oaks, CA: Sage.

Rohana Ariffin. 1999. Feminism in Malaysia: A historical and present perspective of women's struggles in Malaysia. Women's Studies International Forum 22(4): 417-423. https://doi.org/10.1016/s0277-5395(99)00039-4

Roomi, M.A. and G. Parrot. 2008. Barriers to progression of women entrepreneurs in Pakistan. Journal of Entrepreneurship 17(1): 59-72.

Roomi, M. and S. Harrison. 2010. Behind the veil: Women-only entrepreneurship training in Pakistan. International Journal of Gender and Entrepreneurship 2(2): 150172.

Rozita Abdul Mutalib, Rozita Arshad, Nur Syakiran Akmal Ahmad and Zalinah Ahmad. 2015. Women and entrepreneurship: An overview of women entrepreneurship programs in Malaysia. Journal of Governance and Development, Special Issue on Social Entrepreneurship 11: 15-28.

Shaheed, F. 1990. Pakistan's women: An analytical description. Lahore: SANJH.

Shamsul Hana Abdul Rani and Norashidah Hashim. 2017. Factors that influence women entrepreneurial success in Malaysia: A conceptual framework. International Journal of Research in Business Studies and Management 4(1): 16-23.

Shmiln, A.W. 2017. Female entrepreneurs in developing countries: A comparative with developed countries as explorative study. Arabian Journal of Business Management Review 7(5): 331-342.

Sitinor Wardatulaina Mohd Yusof, Juhaini Jabar, Murzidah Ahmad Murad and Rosalina. 2017. Exploring the cultural determinants of entrepreneurial success: The case of Malaysia. International Journal of Advanced and Applied Sciences 4(12): 287297.

Stoner, C.R., R.I. Hartman and R. Arora. 1990. Work home role conflict in female owners of small businesses: An exploratory study. Journal of Small Business Management 28(1): 30-38.

Studholme, S.A. 2013. Women entrepreneurs in Saudi Arabia: Bargaining within a patriarchal society. PhD diss., College of Arts and Social Sciences, University of Aberdeen, United Kingdom.

Syed Shah Alam, Mohd Fauzi Mohd Jani and Nor Asiah Omar. 2011. An empirical study of success factors of women entrepreneurs in southern region in Malaysia. International Journal of Economics and Finance 3(2): 166-175. https://doi.org/ 10.5539/ijef.v3n2p166

Thomas, S. 2012. Narrative inquiry: Embracing the possibilities. Qualitative Research Journal 12(2): 206-221. https://doi.org/10.1108/14439881211248356

UN Women. 2018. UN Women Annual Report. http://annualreport.unwomen.org/en/2018 (accessed November 2018). 
Walby, S. 1990. From private to public patriarchy. In Theorizing patriarchy, eds. S. Walby. Oxford: Basil Blackwell. https://doi.org/10.7202/040760ar

Wazir Jahan Karim. 1995. Male and female in developing Southeast Asia. Washington, D.C.: Berg Publishers.

Xavier, S. 2011. The transition from corporate careers to business ownership: The case for women entrepreneurs in Malaysia. International Journal of Business Administration 2(3):148-160.

Yin, R. 2003. Case study research: Design and methods. 4th ed. Thousand Oaks, CA: Sage.

Yusuf, L. 2013. Influence of gender and cultural beliefs on women entrepreneurs in developing economy. Scholarly Journal of Business Administration 3(5): $117-$ 119. 